\title{
How to Measure the Performance of Social Innovation? Case Study of Hungarian Social Cooperatives
}

\author{
Sándor Bozsik \\ Judit Szemán \\ Zoltán Musinszki \\ Faculty of Economics \\ University of Miskolc, Hungary
}

\section{Keywords}

Balanced Scorecard, Controlling, Human Resource Management, Social innovation, social cooperatives

\begin{abstract}
Innovation is a key element of economic development and a key factor in social processes. Technological and economic innovations cannot respond to all social challenges. However, innovation - the search for new and innovative solutions - needs to be interpreted more broadly than before. In line with social changes, the European Union pays more attention to the context of social innovation. The social enterprises play a vital role in modern societies. The subject of our study is social cooperatives, which are a type of social enterprise. The social cooperatives offer an opportunity to improve the employment skills. However, the management of this enterprises faces several dilemmas how can build up an effective control system of a social enterprises in Central-Europe. As our questionnaire stated, the major problem of social cooperative is the quality of available labour force. This paper focuses the applicability of the traditional Balanced Scorecard system to the special needs of a social cooperative. Here one area of the Balances Scorecard will be highlighted - the Human Resource management and how the tools can be effectively adapted to the social cooperatives. A report system and a ratio analysis tool are developed to help the work of social cooperative managers.

The focus of this paper research question how can improve the monitoring of Human Resource Management in social enterprises like social cooperatives.

In the introduction part of this paper the importance of social innovation is emphasized, and a brief introduction to the development of controlling tools is provided. Next, part of our broader questionnaire is presented to highlight the importance of Human Resource Management in the Hungarian social cooperatives. In the discussion part a special BSC is presented which is based on Bull's social enterprise Business Scorecard system. The Human Resouce Management should consider the regulatory requirements of granting authority, so these are briefly introduced. Finally, some indicators and tables are presented which can help the Human Resource Management in a social innovation enterprise.
\end{abstract}

\section{Acknowledgement}

This research was supported by the project no. EFOP-3.6.2-16-2017-00007, titled Aspects on the development of intelligent, sustainable and inclusive society: social, technological, innovation networks in employment and digital economy. The project has been supported by the European Union, co-financed by the European Social Fund and the budget of Hungary.

\section{Introduction and literature overview}

\subsection{The special features of social enterprises}

The primary economy generally offers little opportunity (neither the market sector nor budget organizations forced to lay off staff) to reduce the long-term unemployment. The core reason of longstanding jobless status is mostly the lack of marketable skills or the inappropriate location of the potential employees. Therefore, non-profit organizations can help to find a solution for this problem. One option may be to support the employment initiatives of non-profit organizations job creation outside the mainstream of the labour market. 
Emmerij (1994) highlighted the importance of social care and a novel interpretation of it. Solidarity thinking, novel work and ethical life appeared as key concepts in his study, and he also considered rethinking the concept of work accepted.

According to Frey (2007), "we see local initiatives as part of the social economy that aim to integrate hard-to-place people into the world of work by offering them employment, skills development and counselling." The basis of the social economy is significant social work is not used in the domestic sense.

\begin{tabular}{|c|c|c|}
\hline \multicolumn{3}{|c|}{ Comparison of social innovation and formal economy } \\
\hline Viewpoints & Social innovation & Formal economy \\
\hline The purpose of the economy & Meeting needs & Economic growth \\
\hline Work motivation & The economy is not an end in itself & Only profit and growth \\
\hline Function of work & $\begin{array}{l}\text { Diversity of motives, incentives, } \\
\text { and goals }\end{array}$ & The work tool, respectively. target \\
\hline The nature of the work & Work is a natural way of being & The economic content of the work \\
\hline Independence of the economy & $\begin{array}{l}\text { The primacy of the social content } \\
\text { of work }\end{array}$ & prioritization \\
\hline $\begin{array}{l}\text { Development of producer- } \\
\text { consumer roles }\end{array}$ & $\begin{array}{l}\text { Economic activity is not } \\
\text { independent, it is intertwined with } \\
\text { social conditions }\end{array}$ & Economic activity \\
\hline The presence of utilitarianism & The producer is also a consumer & $\begin{array}{l}\text { independent, } \\
\text { subsystem }\end{array}$ \\
\hline Systems of interest & $\begin{array}{l}\text { A sense of counting and fairness is } \\
\text { typical }\end{array}$ & Producer and consumer \\
\hline Degree of solidarity & Community interest first & divorce \\
\hline
\end{tabular}

A comparison of Polanyi's substantive economy with the formal economy sheds light on many interesting differences. The social economy is closer to Polányi's idea than the formal economy (Table 1). In the substantive economy, the community interest and the social benefits of work are of paramount importance.

The basic value of the social innovations is that it carries out its activities not for the benefit of the individual, but for the benefit of the community, it seeks to promote the development of communities organized on a territorial basis or along common interests. People in the social economy work together for the common good. In the social economy, social enterprises and cooperatives are significant. Social enterprises serve the community, and their goal is not to maximize profits, the target group is usually the long-term unemployed. In Hungary, the social land program can be considered being a social enterprise nature. (Siposné, 2020; Süveges, 2019)

\subsection{Development of controlling tools from financial statement analysis to Balanced Scorecard}

Financial statements are a structured representation of the financial position and financial performance of an entity. The objective of general-purpose financial statements is to provide information about the financial position, financial performance and cash flows of an entity that is useful to a wide range of users in making economic decisions.

During the analysis of the balance sheet, we can draw conclusions about the property and financial state of the enterprise, and from the cash- flow about its financial state. (Fenyves et al, 2018)

In addition to individual financial indicators, we can also use indicator systems. One of the most popular indicator systems is the Du Pont system. It is based on the idea that non- profit -- as an absolute indicator -- is in the centre, but the Return on Investment (ROI) - as a relative value.

The financial statements' data are typically aggregated data. These highly summarized data give an overall picture of the company's management. They help us to see the problems, and to know where to look for the source of the problems, but it does not give answers for the causes of problems.

Despite the criticism of the use of traditional financial indicators enjoy a great popularity. Their advantages are the simplicity, the availability, and the cheapness. However, their application based on the literatures' recommendation have dangers. (Brealey et al., 2011) 
Nowadays the economic environment of companies has significantly changed: the former permanence was replaced by variability, marketing has come into the focus of operation instead of production, and the knowledge-focused approach has appeared beside the capitalcentred approach. (Veresné Somosi, 2010)

\section{From Financial Indicators to Balanced Scorecard}

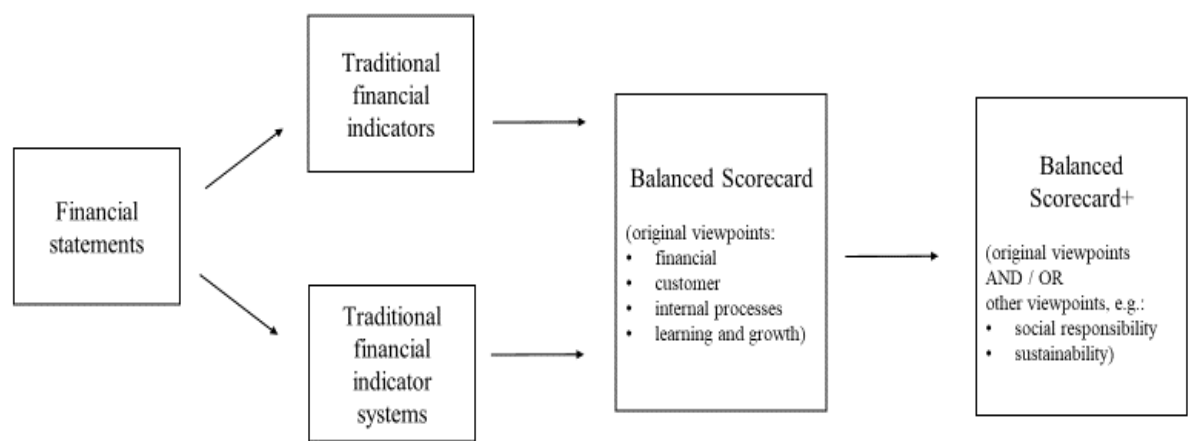

Source: own editing, based on Musinszki and Süveges, 2019

In today's highly competitive environment the financial indicators alone are not able to give direction for the future; typically, they can give a view about some actions of the past, and so are retrospective, post factum indicators. In recognition of the changes, Robert S. Kaplan and David P. Norton developed a balanced, strategy-based indicator system. Both financial and non- financial indicators need to be reflected in the benchmark. The balance between them needs to be created and they need to be united in a complex indicator system. This is achieved by the Balanced Scorecard (BSC). The viewpoints of the basic model - financial, customer, internal processes, learning and growth

However, the basic model was not regarded as a definite model by the model creators. Over the last two decades different types of the basic model have been revealed taking different factors into consideration. The number of viewpoints has expanded like the supplier, the future perspective, the social responsibility viewpoints. (Molnár-Horváth, 2017; Artiach et.al, 2010)

\section{Managerial problems of social cooperative}

One of the issues what we walked around in a questionnaire was the managerial problems of social cooperatives. The question was the following: "Please rank by importance of the following problems in the management of social cooperative" 72 social cooperative managers were asked from region of SouthTransdanubia, Southern Plain, and Northern Plain.

Sixteen potential sources of managerial problems were listed, and the respondents were asked to rank the problems by their seriousness in the economic management of their organisation. The answers are presented in figure 2 . 


\section{Significance of Economic Problems in the Management of Social Cooperatives}

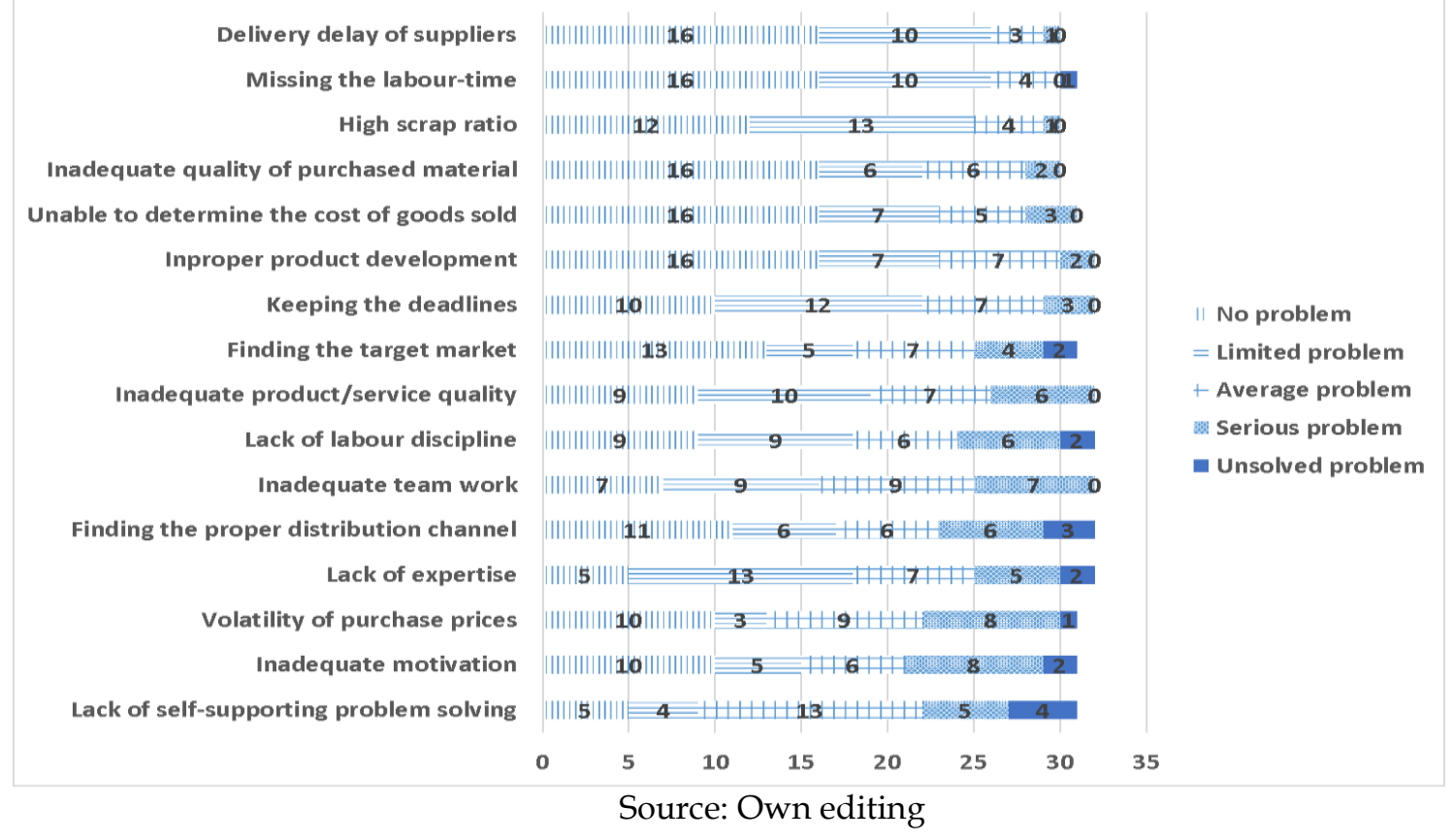

The respondents evaluate the importance of each of the sources at a 5 points Likert-scale. (No problem - 1; limited problem - 2; average problem - 3; serious problem - 4 and unsolved problem - 5) The weighted average of the answers was calculated, where the weights were the number of answers in each category. To calculate the ranking, we took the weighted average of the total answers and ranked them in ascending order, so the less important problem is at the top, while the most important one is at the bottom.

If we look at the rank of the problem, the most serious problems are caused by the improper work force. Lack of self-supporting problem solving - first on the list, Inadequate motivation - second on the list, lack of expertise - fourth on the list, inadequate teamwork - sixth on the list, lack of labour discipline - seventh on the list. Almost every aspect of the work force is critical except of the labour-time which is a negligible problem. It is no wonder, the workers are paid after their working hours regardless to their performance. The condition of granting state subsidy is the employment of the dedicated employees, so if the social cooperatives dismiss an employee, a new one should be taken. Considering the fact, that these social cooperatives are mostly operating in small settlements (see table 2), to find new employees replacing the improper ones are very hard task.

The main aim of the state subsidy is to help the people to transfer from the long-lasting unemployment or public work status to a marketable employment. But the answers to this question indicate, that this transformation is not an easy job. To improve the quality of available work force requires the constant supervision of the management and the targeted training of the employees to satisfy the labour market requirements.

The respondents find the second main problem group in the improper marketing (find the proper distribution channel - ranked at 5th biggest, problem of 16, inadequate product/service quality - ranked at 8 th, finding the target market - ranked at 9th, improper product development - ranked at 11th). The social cooperatives mostly work up local raw materials and selling them in short distance markets. Considering the fact, that they are new, small organisations (see on table 2), their brand strength is very limited. But they cannot compete with prices, because the cost of operation is high due to the improper work force and the limited size of production. To break out from this trap requires proper business cases and perfect implementation of business plans.

The next problem circle related to the uncertainty of purchase (volatility of purchase prices - ranked at 3rd biggest problem). The other problems relating to the purchase are far less important. (Reliability of purchase quality - 13th, delivery delay of suppliers - last one). The quality management of internal 
processes (keeping the deadlines - 10th, unable to determine the cost of goods sold - 12th, high scrap ratio - 14th) is less important.

To sum up our result, the far most important problem of the management of social cooperatives is the improper quality of labour force. Almost every aspect related to human resource management were considered as critical factor. The marketing problems are also important, the issues related to the internal processes and purchase are less significant.

Discussion - traditional Balanced Scorecard, Balanced Scorecard for Social Enterprises, Balanced Scorecard for Hungarian social cooperatives

The main line of our research, how the managers of social cooperatives can use the databases available at their organization to make proper decisions. The framework of the structured usage of databases worked out by Kaplan and Norton (Kaplan and Norton, 1992) and it is called to Balanced Scorecard System (further BSC). The viewpoints of the basic model are the financial, the customer, the internal processes, and the learning and growth viewpoint.

Bull's paper analysed the results of 30 pilot social enterprises utilizing the BSC system. The paper concluded that highlighting both strengths and areas where greater support may be required would be a great help for these enterprises. (Bull, 2006)

He stated that the social enterprises general strengths by his investigation is the learning perspective. (e.g., training and development, participative decision-making and personal development cultures) The other strong area is the vision and strategy creation ability.

The weaknesses are the low level of management system from the accounting to the quality standards. The reason is the shortage of resources like financial literacy, professional skills, and moral hazard.

Bull also modified the original BSC model to social enterprises by modifying the four perspectives into: multi-bottom line (dealing with synthetic assessment of financial, environmental, and social results), stakeholders' environment, internal activities (related to structure, communication, quality, etc.), and learning organization (dealing with training and knowledge management).

\section{Bull's Balance Model and Topic Areas}

\begin{tabular}{|c|c|c|c|}
\hline \multirow{5}{*}{\multicolumn{2}{|c|}{$\begin{array}{l}\text { Return: The multi-bottom line } \\
\text { Social Accounting } \\
\text { Sustainability } \\
\text { Budgets } \\
\text { Social Aims }\end{array}$}} & \multicolumn{2}{|c|}{ A learning organisation } \\
\hline & & & \multirow{5}{*}{$\begin{array}{l}\text { Learning Culture } \\
\text { Improvement } \\
\text { Participation } \\
\text { Knowledge } \\
\text { Continuous Improve. } \\
\text { Training }\end{array}$} \\
\hline & & & \\
\hline & & & \\
\hline & & & \\
\hline $\begin{array}{l}\text { Environmental Aims } \\
\text { Metrics }\end{array}$ & \multirow{2}{*}{\multicolumn{2}{|c|}{$\begin{array}{c}\text { Visioning } \\
\text { (Mission Statement, } \\
\text { Balance Sheet, Business } \\
\text { Plan) }\end{array}$}} & \\
\hline Branding & & & \multirow{6}{*}{$\begin{array}{l}\text { Structure } \\
\text { Communication } \\
\text { Quality } \\
\text { Standards } \\
\text { Frexibility } \\
\text { Performance Measures } \\
\text { ivities }\end{array}$} \\
\hline Promotion & & & \\
\hline Evaluation & & & \\
\hline Stakeholder Focus & & & \\
\hline Market Awareness & & & \\
\hline The stakeholder en & ronment & Internal activities & \\
\hline
\end{tabular}

Source: Bull, 2006

By our review, the main problem of social cooperatives is related to human resources. (Kocziszky et al., 2017) The monitoring of this problem is treated by the human resource and learning perspective of BSC. The key point of the learning perspective is: How can the employees and the management treat the challenges of the continuously changing economic environment, how quick is the implementation of the proper answers? 
The key point of the customer perspective is: How do customers judge the performance of the organization? When designing a customer perspective, it is necessary to identify the customers, market segments where the organization wants to compete. Now the focus is on the learning organisation perspective.

One of the missions of the social enterprises is to help their member to develop and improve the important labour market abilities. Since in the learning organization perspective we inserted new aspects which emphasize the improvement of the competitiveness of the labour force. This part is considered as the most important part of the BSC, because the success of improving the human resource factors will improve the financial perspective.

The stakeholder environment was dramatically restructured. Instead of it we place the requirements of the grantor and regulator public institutions. Most of the social enterprises depends on public funds, so the enterprises should meet the criteria of the state and European funds. The available state funds can be numerous. Especially in the agriculture and country development there are several opportunities. (Olajos, 2020)

Figure 4 shows the result of our considerations. The suggested modification in the original model is bolded.

Further Developed Bull model to the Social Cooperatives

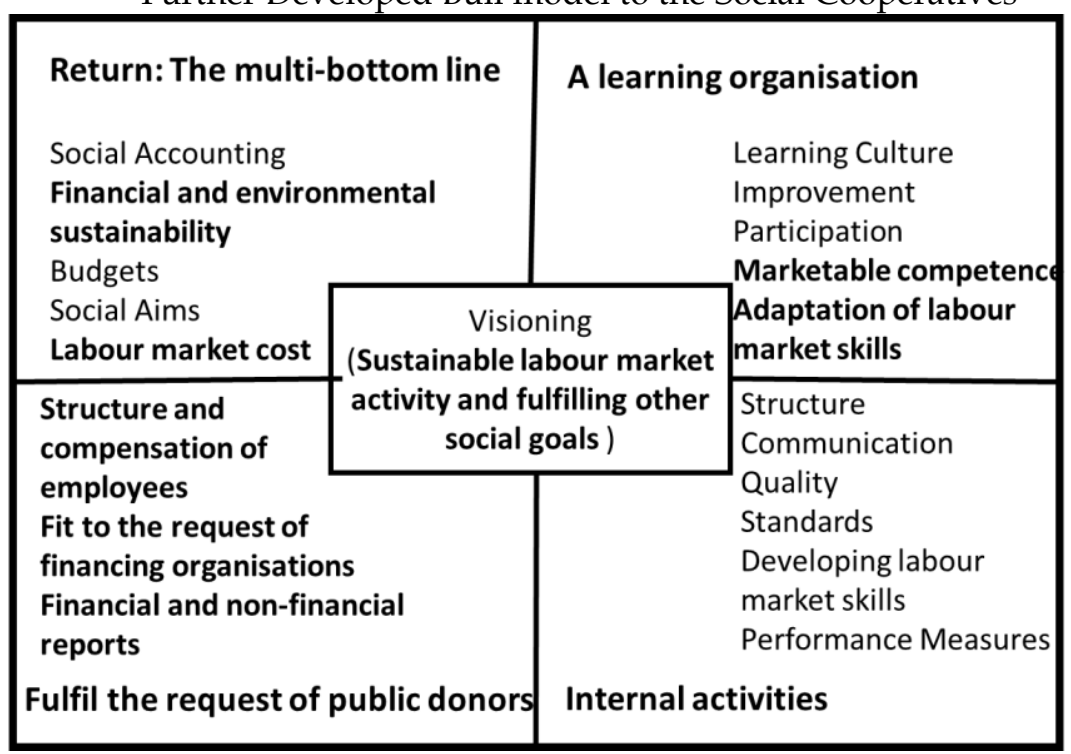

Source: Bozsik et al, 2019

In our point we highlight only the learning organisation perspective, which is important in point of Human Resource Management.

The labour market cost is essential, because the operating state subsidy can cover $50-100 \%$ of this expense. And replacing the state subsidy with own revenue is the key success indicator of the social cooperative. The proposed indicator here is the operating state subsidy/total labour cost - which should be reduced over time. Other indicator can be the operating state subsidy/operating profit. If the ratio is less than one, the organisation can be considered as a sustainable organisation, because it is able to survive without the operating state subsidy. (Lipták, 2017)

The above indicators are used to measure the result of the operations, but they are unable to measure the reasons of the success or failure. From the questionnaire you can see that the major problem is the quality of available work force. So, the improvement of the human resource by learning and by motivating is essential. The upper right quarter of our proposed BSC related with issue.

The marketable competence can be measured by several indicators, but they are industry specific ones. Each industry requires special features. For manufacturing enterprises, the proper quality of craftsmen can be regularly tested, and the essential training program should be introduced. Here the 
proposed indicators are the ratio of skilled and unskilled labour force. The successful completion of vocational training programs is also worth measuring. To improve the teamwork and the motivation independent projects should be launched with the management of a team leader. The goal and reward of these projects should be specifically determined, and their continuous monitoring is required.

\section{Regulatory framework of the Human Resource Management in a Hungarian Social Cooperatives}

The importance of human factor is vital in the operation of any enterprise. The Human Resource Management is not else than the implementation of traditional controlling methods (e.g., goal setting, planning, plan-fact analysis, corrective actions). The main aim of a general Human Resource Management is to give a real, transparent, actual overview on the staff's employment skills and to give advice how to face the different challenges like recruiting, career planning, dismissing, employee satisfaction. The financing issues are also part of this job - payroll calculation, working out material incentives, efficiency analysis of labour force.

Human Resource Management should consider the regulatory environment - the Hungarian social cooperatives should comply not only with the general accounting rules, but also the special requirements of the granting authority who wants to monitor the activity of the management.

The social cooperatives can be established by the Act on Cooperatives (2006/X.) The special rules of social cooperatives are determined by the government order 141/2016. An application was written out for supporting the creating social cooperatives called „Focus programme for promoting social cooperatives with local government membership". (Fókuszban ..., 2016)

Most of the social cooperatives are established to utilise the opportunities offered by the Focus programme. The condition of this application was that at least two of members should be earlier public worker, and the employees should be former unemployed, student or pupil. (Katonáné et al., 2017) The requirements of the application related to the Human Resource Management were the followings:

The social cooperatives should ensure new and long-term employment up to 2020 for those, who were former unemployed, or public workers.

The social cooperatives can apply for a subsidy up to 7,5 million forint/annum/person (approx. 20 400 euro) to cover the gross wage and social contribution tax. In the first year the sum of subsidy can reach the $100 \%$ of this amount, in the second year it decreased to $90 \%$, in the third year to $80 \%$.

One project manager can receive a monthly payment up to the twice of the minimal wage + its contribution tax and travelling cost from this subsidy.

At least two members of the social cooperatives should take part a social manager training, and annually at least 6 members should attend in a two-day community building training.

Every half a year the social cooperatives can require advisors from one of the following areas (Labour Law, Finance, Sustainability or Marketing Management), and annually it can be supplied with consultant in field of organisational development or rationalization or Human Resources Management. These external experts and the trainings are financed by the supervisory authority called OFA (National Employment Fund).

Besides this it can be applied for additional and optional advisory support like technical advisory work for implementing investments and equipment purchase, commercial activities.

To monitor the activity of the social cooperatives the supervisory authority also requires regular reports. Some of them are also related to the Human Resource Management. These are the followings:

Monthly report on the number of employment (in- and outgoing staff)

Quarterly report on the professional progress of employee taking part in various development programmes.

Quarterly report on involvement of external advisors (goal, task, evaluation of success)

\section{Offered controlling solutions and indicators}

To meet the regulatory framework, the social cooperatives require carefully planning of employment. The managers should consider meeting the requirements of application during the decision making. The level of employment is important condition of granting subsidies, so more emphasis is needed to develop the skills and attitude of existing labour force rather replacing them with more motivated and skilled 
ones. The regular training programmes and the acquirement of foreign experts also supports this approach.

The base and starting point of any budget process is the personal file which need to be updated for each of the employee. The proposed content of this file is in tables below:

Descriptive Data of Employee:

\begin{tabular}{|l|l|}
\hline Description & Data \\
\hline Name: & \\
\hline Tax number: & \\
\hline Sex: & \\
\hline Position: & \\
\hline Graduation: & \\
\hline Professional skills: & \\
\hline Special abilities: & \\
\hline Family status: & \\
\hline Other tax allowances: & \\
\hline Health status: & \\
\hline Date of recruitment: & \\
\hline
\end{tabular}

Source: own editing

The data on family status and health status is not only important, because it helps characterise the employees, but also important information to acquire the tax allowances in personal tax. The other tax allowances regard mainly to the social contribution tax allowances.

Besides the qualitative information, information about the financial incentives is also worth to record. We need them to meet the data service requirements of the authorities and to complete the tax declarations.

Outgoing Payments and Incentives

\begin{tabular}{|l|l|l|l|l|}
\hline Payroll/Sick payment/Benefits in kind & $\begin{array}{l}\text { Length of time (in } \\
\text { month) }\end{array}$ & Salary & $\begin{array}{l}\text { Social } \\
\text { contribution }\end{array}$ & Total \\
\hline Period & & & & \\
\hline & & & & \\
\hline
\end{tabular}

Source: own editing

Table 3 summarises the content of three tables, whose purpose can be read in the headings. We should separate the salaries from the benefits in kind and sick payment, while their taxation is different.

The third element of the personal file or record is the information about the employee's personal development. Its structure is below:

Record on Personal Development

\begin{tabular}{|l|l|l|l|l|}
\hline Personal development & \\
\hline & $\begin{array}{l}\text { Type of } \\
\text { training }\end{array}$ & Graduation & Potential use & Actual use \\
\hline & & & & \\
\hline & & & & \\
\hline \multicolumn{5}{|c|}{ Source: own editing }
\end{tabular}

The second input of the Human Resource Controlling is the strategic plan of the social cooperatives. In budgeting the management should make decisions on the personal development of the employees and 
on the application for external experts. If theses strategic decisions are made, the management can budget and monitor the Human Resource Activity by using the following tables.

Labor Cost Budget

\begin{tabular}{|c|c|c|c|c|c|c|c|c|c|}
\hline \multirow{2}{*}{\multicolumn{2}{|c|}{ Labour cost budget }} & \multicolumn{3}{|c|}{ Month } & \multicolumn{5}{|c|}{ Total } \\
\hline & & January & $\ldots$ & December & Q1 & Q2 & Q3 & Q4 & Total \\
\hline \multirow{3}{*}{ Salary } & Budget & & & & & & & & \\
\hline & Actual & & & & & & & & \\
\hline & \begin{tabular}{|l} 
Difference \\
\end{tabular} & & & & & & & & \\
\hline \multirow{3}{*}{ Social contribution } & Budget & & & & & & & & \\
\hline & \begin{tabular}{|l|} 
Actual \\
\end{tabular} & & & & & & & & \\
\hline & Difference & & & & & & & & \\
\hline \multirow{3}{*}{ Sick payment } & Budget & & & & & & & & \\
\hline & Actual & & & & & & & & \\
\hline & Difference & & & & & & & & \\
\hline \multirow{3}{*}{ Benefits in kind } & Budget & & & & & & & & \\
\hline & Actual & & & & & & & & \\
\hline & \begin{tabular}{|l} 
Difference \\
\end{tabular} & & & & & & & & \\
\hline \multirow{3}{*}{ Total } & Budget & & & & & & & & \\
\hline & Actual & & & & & & & & \\
\hline & Difference & & & & & & & & \\
\hline
\end{tabular}

Source: own editing

Table 5 is simply an aggregation of the financial outgoing part of the personal files. In the beginning of the year the management budgets the future payments and compares with the actual payments. The figures are aggregated quarterly (see Q1, Q2, Q3, Q4) and annually. The quarterly aggregation is necessary to complete the quarterly report to the supervisory authority.

The table can be extended with the source of labour cost (e.g., amount of state subsidy and own source).

Budget on Personal Development

\begin{tabular}{|c|c|c|c|c|c|c|}
\hline \multicolumn{2}{|c|}{ Personal development } & Q1 & Q2 & Q3 & Q4 & Total \\
\hline \multirow{3}{*}{$\begin{array}{c}\text { Social management } \\
\text { training }\end{array}$} & Budget & & & & & \\
\hline & Actual & & & & & \\
\hline & Difference & & & & & \\
\hline \multirow{3}{*}{$\begin{array}{c}\text { Community building } \\
\text { programme }\end{array}$} & Budget & & & & & \\
\hline & Actual & & & & & \\
\hline & Difference & & & & & \\
\hline \multirow{3}{*}{ Other occassions } & Budget & & & & & \\
\hline & Actual & & & & & \\
\hline & Difference & & & & & \\
\hline \multirow{3}{*}{ Total } & Budget & & & & & \\
\hline & Actual & & & & & \\
\hline & Difference & & & & & \\
\hline
\end{tabular}

Source: own editing

The following tables contain information about the budgeted and actual personal development actions. Each of the budgeted and actual actions should be registered in the personal files too. 
Supportive Actions

\begin{tabular}{|c|c|c|c|c|c|c|}
\hline \multicolumn{2}{|c|}{ Supportive actions } & Q1 & Q2 & Q3 & Q4 & Total \\
\hline \multirow{3}{*}{ Accounting\&Finance } & Budget & & & & & \\
\hline & Actual & & & & & \\
\hline & Difference & & & & & \\
\hline \multirow{3}{*}{$\begin{array}{l}\text { Marketing \& } \\
\text { Commercial }\end{array}$} & Budget & & & & & \\
\hline & Actual & & & & & \\
\hline & Difference & & & & & \\
\hline \multirow{3}{*}{ Technical } & Budget & & & & & \\
\hline & Actual & & & & & \\
\hline & Difference & & & & & \\
\hline \multirow{3}{*}{ Total } & Budget & & & & & \\
\hline & Actual & & & & & \\
\hline & Difference & & & & & \\
\hline
\end{tabular}

Source: own editing

The supportive actions depend on the management of the social cooperatives. Besides the quantitative data, it would be useful to store data about the advisory problem, the persons involving in the advisory work and the usefulness of the advisory report in point of future success.

To monitor the state of staff, some traditional human resource indicators also can be used. The indicators should be measured quarterly, and the tendency reflects the improvement or deterioration of staff satisfaction. The ratios support the balance scorecard mechanism.

In case of social cooperatives, the labour cost ratio is recommended, as a key performance indicator.

Labour in value added ratio $=\frac{\text { quarterly labor cost (thousand forint) }}{\text { value added (thousand forint) }}$

The value added is the difference between quarterly sales and quarterly material cost and other expenses except of depreciation and labour cost. Since the labour cost and most of the asset purchase is presently financed from state subsidy, the current value of ratio can be higher than 1 . However, the economic entity should be sustainable, so the major aim of the social company to reduce this ratio to less than 1. The lower the ratio, the higher the amount, which the company can devote for further development and investment. This ratio can be distributed into three further indicators in the following way:

Labour in value added $=$ Labour economical * Labour efficiency * Labour effectiveness

The ratios are interpreted below:

Labour economical ratio $=\frac{\text { labour cost }(\text { 1housand forint) }}{\text { potential working days (head } * \text { days })}$

The dimension of this ratio is forint/head/days. In case of social cooperatives its value mostly depends on the current level of daily minimal wage. The higher than minimal value indicates higher generosity of social cooperatives or higher ratio of skilled labour.

Labour efficiency ratio $=\frac{\text { potential working days (head } * \text { days })}{\text { active working days (head } * \text { days })}$

The ratio can be 1 or higher. If the ratio is 1 , every employee works during the month. The potential minimum is likely not reached. The paid and unpaid holidays, the sickness can increase this figure. A sharp increase in this ratio indicates a mass holiday, but also a worsening attitude of labour activity.

Labour effectiveness ratio $=\frac{\text { active working days (head } * \text { days) }}{\text { quarterly sales (forint) }}$ 
The dimension of this ratio is head*days/forint. It measures how many labour times is required to produce one thousand forints value added. The lower the ratio, the better the effectiveness of the labour.

Not the absolute size of the ratios is important, but the size of their changes, which we can discover a logarithmical distribution in the following way.

$$
100 \%=\frac{\ln (\triangle E C O)}{\ln (\Delta L V A)}+\frac{\ln (\Delta E F I)}{\ln (\Delta L V A)}+\frac{\ln (\Delta E F E)}{\ln (\Delta L V A)}
$$

where:

$\triangle \mathrm{LVA}$ - ratio of two comparable labour in value added ratio

$\triangle \mathrm{ECO}$ - ratio of two comparable labour economical ratio

$\triangle \mathrm{EFI}$ - ratio of two comparable labour efficiency ratio

$\triangle \mathrm{EFE}$ - ratio of two comparable labour effectiveness ratio.

\section{Conclusions}

As we can see from the questionnaire, the Human Resource Management plays a vital role in the social cooperative management. A controlling system was developed to monitor and to observer the current state and the development of labour force in social cooperatives. The proposed managerial control system consists of two parts.

A table structure was developed to fulfil the requirements of the reporting system determined by the regulatory authority. The tables focus the cost of labour, the development of human resource and the supportive actions. The proposed frequency is in case of individual record is monthly, for aggregated figures quarterly.

A ratio analysis tools was implemented to analyses the current state and the development of labour force. The analysis monitors the utilization of human resource and identifies three driving factors:

Economical factor measures the cost of labour per potential working days.

Efficiency factor measures how relates the potential working days to the actual working days.

Effectiveness factor measures the productivity of the available labor source.

The ratios can be calculated not only the cooperative aggregate level but can examine in different product lines if they exist.

\section{Limitations}

The above offered tables (namely table 2, 3, 4, 5, 6, 7) are specialised to comply the data request of granting authority, but can be widely used, if the quality of the available labour force is a vital issue in a social enterprise. Table 2 is a general record structure which should be maintained in every enterprise. The cost-benefit analysis is the core duty of any management, and the development of labour force skills is very important in social cooperatives. Table 4 shows the development, while table 3 shows the cost at the level of a single person, while table 5 and table 6 record it at an aggregate level. Table 7 serves only special purpose to comply the data request of this special granting programme.

The developed indicators - the labour economical ratio, the labour effectiveness ratio and the labour efficiency ratio are offered to use generally in every social enterprise or any public institutions which have own revenues. These ratios can be considered as an implication of the EU budget rules - $3 \mathrm{E}$ on field of Human Resource Management (Otrusinova - Pastuszkova, 2012).

\section{References}

Artiach T., Lee D., Walker J. (2010) The determinants of corporate sustainability performance Accounting and Finance Vol. 50, Issue 1, pp. 31-51. https://doi.org/10.1111/j.1467-629X.2009.00315.x

Bozsik S., Musinszki Z., Szemán J (2019) A Central European approach to the typology of social enterprises in: Proceedings of the 13th International Conference of Strategic Management and its Support by Information Systems SMSIS 21-22 May 2019 Ostrava Czech Republic ISSN: 2570-5776, 25-32.

Brealey R. - Myers S. - Allen F. (2011). Principles of corporate finance McGraw-Hill/Irwin, New York, 10th Edition Bull M. (2006). 'Balance' The development of a social enterprise business performance analysis tool - The Third Annual Social Enterprise Research Conference 22-23 June 2006 London South Bank University http://dx.doi.org/ 10.1108/17508610780000721 
Csoba J. (2007) Processes that bring the social economy to life [A szociális gazdaságot életre hívó folyamatok] In: Frey M. (ed.): Manual of Social Economy [Szociális gazdasági kézikönyv] Pátria Nyomda. Budapest

Emmerij L., (1994) The employment problem and the international economy. International Labor Review. 144/4, 449466.

Fenyves V. (et al.) (2018) The Role of the Notes to the financial statements in corporate decision-making corporate ownership and controls 15(04), 138-148.

Frey M. (ed.) (2007) Manual of Social Economy [Szociális gazdasági kézikönyv] Pátria Nyomda. Budapest

Kaplan, R. S., Norton, P. D. (1992). The Balanced Scorecard - Measures that Drive Performance Harvard Business Review, 92/1-2, 71-79.

Katonáné J. - Varga E. - Nemes G. (2017) The focus is on the process of social innovation in the Hungarian countryside [Fókuszban a társadalmi innováció folyamata a magyar vidéken] Észak-magyarországi Stratégiai Füzetek Vol. 14, No. 1, pp. 6-19.

Kocziszky, Gy., Veresné, S.M. and Balaton, K. (2017) Experiences and development opportunities of social innovation research [A társadalmi innováció vizsgálatának tapasztalatai és fejlesztési lehetőségei] Vezetéstudomány, Vol. 18, No. 6-7, pp.15-19.

Lipták K. (2017) Analysis of human potential in settlement level in Hungary [Települési humán potenciál vizsgálata Magyarországon] Észak-magyarországi Stratégiai Füzetek Vol. 14, No. 2, pp. 55-64.

Molnár V., Horváth D. (2017) Determination of Coefficients of Multi-Attribute Utility Function with Attribute Breakdown Proceedings of the 12th International Conference on Strategic Management and its Support by Information Systems Ostrava, 2017., 312-319.

Musinszki Z., Süveges G. (2019) Strategic decision-making supported by traditional financial indicators Oradea Journal of Business and Economics Vol. 4, No. 1., pp. 29-37

Otrusinova M., Pastuszkova E. (2012) Concept of 3 E's and Public Administration Performance International Journal of Systems Applications, Engineering \& Development Issue 2, Volume 6, 171 - 177.

Olajos I. (2020) The young farmer thematic sub-program as a key tool of the support system [A fiatal gazda tematikus alprogram, mint a támogatási rendszer kiemelt eszköze] Publicationes Universitatis Miskolciensis Sectio Juridica at Politica Vol. 37, No 2, pp. 395-415

Siposné Nándori E., (2020) The role of social enterprises in the labor market [A társadalmi vállalkozások munkaerőpiaci szerepe] Területi Statisztika, Vol. 60, No 2, pp. 211-223. https://doi.org/10.15196/TS600205

Süveges G., (2019) The relationship between aims, methods and their financial aspects in the case of social innovations in the field of district heating. Oradea Journal of Business and Economics IV. Special Issue pp. 29-38 ISSN: 25011596 2501-3599

The focus is on the support program for social cooperatives with municipal membership [Fókuszban az önkormányzati tagsággal rendelkezó szociális szövetkezetek támogatási program] http://palyazatok.org/wp-content/2016/07/Palyazati_felhivas_utmutato.pdf

Veresné Somosi M. (2010) The Self-Evaluation Model of Organizational Behavior European Integration Studies, 2010/1., pp. 227-237. 